\title{
ADVERBIALS USED METONYMICALLY IN CONSTRUCTIONS
}

\author{
Olga Repnik \\ UJD Doctoral School Jan Dlugosz University in Czestochowa \\ (Czestochowa, Poland) \\ e-mail: olga_repnik@yahoo.com \\ ORCID: 0000-0003-2672-4149
}

An analysis of the presence of the adverbial / sirconstant component in speech postulates another type of constraint on the joint occurrence of the mandatory and optional components of sentence constructions. Restrictions on the choice of the adverbial / sirconstant component in a simple sentence, depending on the pair of the propositional structure and the denotative region when forming the meaning of the sentence, require genre categorization or context. To avoid misunderstandings about the meaning of the utterance by the addressee and the addressee, the grammar of the constructions offers a higher level of organization of semantic-syntactic relations, namely: a complex sentence, super-phrase unity, paragraph, text.

Keywords: Construction Grammar; metonymy; obligatory and optional constituents; an adverbial component; arguments; attributes; attended circumstances.

\section{Репнік Ольга. Обставини та їх метонімія в конструкціях.}

Аналіз адвербіальної / сирконстантної складової в мовленні постулює ще один вид обмежень обмежень спільної наявності обов'язкових $i$ факультативних компонентів конструкцій речення. Обмеження вибору адвербіального / сирконстантного компонента в простому реченні, залежно від пари пропозиціональної структури і денотативної області при формуванні змісту речення, вимагають жанрової категоризації або контексту. Щоб уникнути різного розуміння суті висловлення в адресата і адресанта, граматика конструкиій пропонує вищий рівень організаиії семантико-синтаксичних зв'язків, зокрема складне речення, надфразову єдність, абзаи, текст.

Жанрово-стилістична належність тексту визначає функиійний аспект простору. У художній літературі простір персонажа виконує дві основні функції: локалізація і характеризація. 3'ясувалося, щзо провідну роль у формуванні простору персонажа-С (суб'єкта) в художній літературі відіграють дієслова руху, зокрема дієслова руху суб'єкта, щчо визначають динамічну природу изього типу простору. Референт імені в «локативній» позииіі - ие не індивідуалізований об'єкт в одній конкретній ситуації, а об'єкт, узятий безвідносно до окремих ознак, змодельованих як узагальнено абстрактні. Форма предиката і загальний референтний статус групи локативних іменників не байдужі один одному.

Ключові слова: граматика конструкцій; метонімія; обов'язкові $i$ факультативні складові речення; адвербіальний компонент; актант; атрибут; сирконстант.

«Yo soy yo y mi circunstancia» «I am myself and my circumstances» Jose Ortega y Gasset

Compositional syntax singles out two types of sentence modifiers, the socalled classifiers or characterizers of the signifying part of the sentence semantic $C$ structure and proposition of the sentence: attributes for arguments () Repnik O., 2019 or octants and circumstantial component for predicates. This 
paper suggests the worked-out terminology for situational roles and argumentative positions of circumstances alongside with the already existing terms of the previous research works in construction grammar and compositional and semantic syntax.

According to many syntactic theories octants claim to form the obligatory members of the situation or event but alongside with octants the structures of proposition may comprise objects denoting various adverbial modifiers of the situation. Every predicate has the ways and manners of its argumentative structure performance and expression as well as their cases and circumstantial component which may be seen as the inner or outer characteristics of the situation.

The ways and manners of the characterizers in the referential semantics of a sentence may differ depending on the sentence analytical level. The characterizer plays the role of the inner propositional circumstantial component the denotation area given, besides, it may take up octant positions as well when and if there is the law of empathy.

\section{«Change of State as Change of Location»}

It would be not an exaggeration to say that analytical languages (English, for instance) tend to be the languages of construction in syntax. As, for example, the resultative construction on Logic (that reflects the change of state) is motivated by the causative construction of movement in syntax (that reflects the change of location). Therefore, a concrete narrower semantic area - movement - is donor and may sponsor a more abstract and broader area - result; i. e. the theory of metaphor adds up to the construction grammar [Miller 1998].

e.g. X caused Y to become Z. // He moved it back. // (cause-motion construction)

The so-called way-construction (construction of movement + direction $=$ route) is made up of two creative constructions, those of the creative construction of route and the intransitive construction of dis-location (unlimited process). the prison.

e.g. Frank dug his way out of the prison. // He made a path. + He moved out of

Therefore, way-construction (the construction of route) is further subdivided into two: the principle construction that describes the means of movement, and the subordinate one, that describes the manner and way of doing it, and this is possible to happen because the manner or way (as well as instrument) in the language is often 'glued' to the the notion of 'how' in semantic syntax.

Cf. e.g. with a knife // with care //

Or, there is another example when syntactically intransitive verb to sneeze may be incorporated into the construction of movement causation:

e.g. He sneezed the napkin off the table.

The constructions belong to the signifying aspect of the semantics of a sentence, i. e. to the logical and semantic proposition of the denotation area given, while the situation given is changing given rise to the modification of its denotation meaning as an item of a sentence. The above-mentioned grammaticalisation and metaphorisation causes the addressee to anticipate an item at a higher syntactic level - utterance, paragraph, text. And here, if the circumstantial component is carried out by a prepositional phrase, serves the role of 'enwoven' proposition in itself, and then, the semantics of the inner and outer characterizers may look as follows (look the Table below): 


\begin{tabular}{|l|l|l|}
\hline \hline Semantic-syntactic function & Characterizers' semantic role & $\begin{array}{l}\text { Characterizers' } \\
\text { supplementary } \\
\text { characteristics }\end{array}$ \\
\hline PLACE & Where the event takes place & $\begin{array}{l}\text { - inro-locatives } \\
\text { - trans-locatives } \\
\text { - environment of the event }\end{array}$ \\
\hline TIME & When the event takes place & absent \\
\hline MANNER & $\begin{array}{l}\text { The ways and manners of the } \\
\text { procedure }\end{array}$ & $\begin{array}{l}\text { - qualitative / evaluation } \\
\text { characteristics } \\
\text { - intensiveness / speed } \\
\text { - additional circumstances }\end{array}$ \\
\hline AIM & $\begin{array}{l}\text { What is the purpose of the } \\
\text { event }\end{array}$ & absent \\
\hline
\end{tabular}

The suggested role-situational classifier includes 4 types of deep-structure semantic functions of the circumstantial component and, in a way, enables us to comprehend the deeper underlying sense of the situation with the verbs of movement thanks to the process of singling out the inner and outer characterizers.

The full description of the verb semantics may be fulfilled by means of pointing out all the parameters needed to characterize the activity of the situation. The semantic meaning of the verb comprises the already-named situation, which, in its turn, comprises the adverbial semantic meaning therefore, the verb has broader and wider contextual connections and links.

Not only the idea of movement may be incorporated in the meaning of the verb but also the manner of movement and thee direction of movement. For the category of the situation with the verbs of movement there are two components characteristic of and universal in any human language: its cause / reason and the manner or way of its achievement.

If we have a closer look at the notion of the characterizer / modifier in a sentence in terms of Generative Grammar, then it may be defined in terms of unlimited constituent that may limit the possible referential scope of another / the other unlimited constituent.

By means of paraphrase, without changing the situation of unlimited and telic process, without the addresser's component, - here you are, - the sentence may represent the intransitive construction of dis-location.

The genre and stylistics of the text determine the space functional aspect. In fiction the space of the personage carries out two main functions: locational and characteristic one. The dynamics of the subject - the main hero in the text - is determined mostly by the verbs of movement, and, in particular, be the dislocation through different circumstances. Therefore, it makes the space and location and placement, as well as movement, dynamic [Aronoff, Rees-Miller 2003].

The genre-stylistic affiliation of the text determines the functional aspect of space. In fiction, the character's space performs two main functions: localizing and characterizing. It was found out that the leading role in the formation of the character-C (subject) space in fiction is played by the verbs of movement, in particular, the verbs of the subject's movement, which determines the dynamic nature of this type of space.

The referent of the name in the «locative» position is not an individualized object in a single concrete situation, but an object taken in the distraction from individual signs, modeled as abstract-generalized. The form of the predicate and the general referential status of the locative noun group are not indifferent to each other. 
The difficulty is to avoid semantic ambiguity posed due to the fact that linguists have different approaches to the problem of syntactic relations between elements and to the very concept of syntactic representation. Depending on the interpretation of this cardinal concept of syntax, the problems of dividing the phrases under study, the functional purpose of their components, and also problems of the terminology are the ones to be solved [Федорова 1992].

Following the traditional views, two types of syntactic representation can be distinguished: 1) a syntagmatic connection expressing a direct connection and the relationship between words in the speech chain and 2) a transformational connection based on transformational (paradigmatic) relations.

There is no strict correspondence between the surface and deep structure of the phrase. Then there is a contradictory opinion regarding the analysis of such phrases by sentence members - a psycholinguistic analysis shows that phrases of the same construction-design with semantically homogeneous verbs have a different semantic structure.

A full description of the semantics of the verb can be achieved by indicating all the parameters necessary to characterize the activity. In the meaning of the verb, the so-called situation is summarized and includes the adverbial component, which provides it with wider contextual connections in speech.

\section{Optional and Obligatory Constituents}

If we consider the concept of a modifier in a sentence from the point of view of informal logic, then it can be defined as a direct component that limits the possible scope of reference of another direct component (constituent). In the sentence the woman wept in the bathroom', the adverbial constituent 'in the bathroom' serves as an adverbial and modifies the «nuclear» structure of 'the woman wept' by specifying the place where the action described by the «nuclear/head» takes place.

The reference to the term 'scope' is also constituted by the adverbial modifier: in other words, the scope of the adverbial 'in the bathroom' is also in the head structure of 'the woman wept'. Obviously, syntactic modifiers are optional components.

The scope of the adverbial modifier can, to some extent, be reflected in the essence and ruled by the syntactic structure: the adverbial construal is included as an optional component of the clause, i.e. its scope is the other components of the sentence, in other words, the 'head' structure itself. Consequently, adverbial expressions such as 'in the bathroom' serve as obligatory components of a clause and modify the sentence as a whole.

Let us consider how the denotative meaning of a sentence due to the adverbial component can be modified using another denotative area as an example - the situation with verbs of inactive physical effect. models:

The 'She looked hard' sentence can be represented by two direct component

1. $\mathrm{NP}+\mathrm{VP}+\operatorname{adv}$ (manner)

2. $\mathrm{NP}+\mathrm{VP}(\mathrm{V}+$ pred adj $)$

In the first model, 'hard' is morphologically a member of the adverbial class (cf. she looked intently, she looked carefully, etc.), while in the second model, 'hard' is morphologically interpreted as a predicative adjective (cf. she looked pretty, she looked careful, etc.). Mutual belonging to different morphological classes leads to ambiguity at the sentence level. An accurate, vague interpretation of the situation requires a level of a higher language unit or context. 
Accordingly, we can conclude that the obligatory components of the sentence always serve as a 'head' structure, but not always the nuclear constituents are mandatory and sufficient enough to determine the denotative meaning of the clause or sentence, since its direct dependence on the adverbial component is observed.

\section{Constraints on the Selection of Components}

Selection Restrictions

In our everyday use of the language, we do not think and do not expect that not all linguistic forms have the property of being shared with any other linguistic form/meaning pairings. For example, intransitive verbs cannot meet together in some nominative-predicative constructions; transitive verbs, on the contrary, can and should 'meet' with a certain nominative-predicative groups. The specificity of such restrictions on joint occurrence is called 'strict sub-categorization' and, presumably, information on such restrictions should be included in dictionaries and included in the vocabulary of native speakers.

Our analysis of the presence of the adverbial component gives rise to another type of co-occurrence restriction - 'the restriction on the choice of the adverbial component' - and raises the problem-solving of whether it should also be included in the description of the interaction of the propositional structure and the denotative area of the form/referential meaning of the sentence.

\section{REFERENCES}

Aronoff, M. \& Rees-Miller, J. (2003). The Handbook of Linguistics. Wiley-Blackwell, $824 \mathrm{p}$.

Miller, A. (1998). Philosophy of the Language. Routledge, 368 p.

Федорова, Н. Н. (1992). Синтаксико-семантический потенцииал глаголов перемещения в английском языке. Дисс. ... канд. филол. наук : 10.02.04. Минск, 220 с. 